\title{
on_education
}

Journal for Research and Debate

\section{reply: a response to cultivating reasonableness in future citizens by elizabeth edenberg}

\author{
Pamela Callahan
}

In "Cultivating Reasonableness in Future Citizens," Edenberg (2018) posits that developing the Rawlsian conception of "reasonableness" (p. 2) in students has the power to eventually "cultivate a citizenry that has robust respect for all people as free and equal" (p. 2) and to encourage discussion across lines of difference. Edenberg and Rawls agree that disagreements must uphold a "common core of respect" (p. 3), which recognizes "the free and equal status of all" (p. 3) citizens.

Keywords: reply

In "Cultivating Reasonableness in Future Citizens," Edenberg (2018) posits that developing the Rawlsian conception of "reasonableness" (p. 2) in students has the power to eventually "cultivate a citizenry that has robust respect for all people as free and equal" (p. 2) and to encourage discussion across lines of difference. Edenberg and Rawls agree that disagreements must uphold a "common core of respect" (p. 3), which recognizes "the free and equal status of all" (p. 3) citizens. Adopting Rawls' "second basic aspect of reasonableness" (p. 3), Edenberg acknowledges that some situations will not meet the minimum standard for mutual respect, but "those who meet the minimal threshold of recognition will not all hold the same comprehensive" (p. 3) values or religion. Differences in values and religion may lead to disagreements, but mutual respect and reasonableness will keep them from devolving into "judgments about the moral character" (Edenberg, 2018, p. 4) of those on the opposite of a debate.

I agree with the basic premise of Edenberg's argument that practice navigating disagreements is a vital component of civic education. Democratic participation requires citizens to engage in discussions, so civic education should include opportunities for students to develop the virtues necessary to engage in discussion especially across lines of difference. I also agree that developing reasonableness in children (and adults) is a viable solution to navigating disagreements. One of the most attractive contributions of Edenberg's call for reasonableness is the fact that the invocation of reasonableness during disagreements evolves from acceptance by all participants of a "common core of respect". Eric Posner (2015) argues that trigger warnings are necessary to protect students on their path to adulthood. Posner's argument for trigger warning conflates the distinction between the harm of person and disagreement of ideas. By employing reasonableness when entering into a conversation, participants accept the "free and equal" (Edenberg, 2018, p. 3) status of all participants and agree to the "common core of respect" for each other (p. 3). As a result, discussions center on the exchange of ideas, instead of a weaponized exchange, thus eliminating the need for students to be protected. Often trigger warnings act as a mechanism to end a discussion before it even begins. Decreasing the use of trigger warnings increases the opportunities for citizens to engage in conversation across lines of difference. When the occasion for conversation across lines 
of difference increases, such an occasion disrupts the opportunity for "racist, sexist, and homophobic rhetoric" (Edenberg, 2018, p. 2) to fester in isolated cells (Zimmerman, 2016). Engaging in conversations, especially those across lines of difference, from a place of respect and reasonableness burdens certain individuals more than others, but these discussions force hateful rhetoric to be examined under the light of the public sphere (Levinson, 1998). I agree with Edenberg (2018) that engaging in conversations with reasonableness is an important ingredient for developing "a citizenry that has robust respect for all people as free and equal."

Although developing reasonableness should be a component of a student's civic development, Edenberg's does not indicate the way(s) reasonableness will operate if citizens deem a specific viewpoint unworthy of respect and reasonableness. Opting out or refusing to engage in conversations across lines of difference poses a significant threat to Edenberg's overarching goal of developing a citizenry capable of discussing controversial issues. Like Rawls, Edenberg (2018) adopts a minimum threshold to determine eligibility for reciprocal respect and reasonableness where demonstrations of "domination and subordination" (p. 3) indicate ineligibility for reciprocal respect and reasonableness. Edenberg does not provide a clear definition for either domination nor subordination. The lack of specific definitions seems to imply that all citizens will arrive at similar or at least complementary conceptions of domination and subordination. If citizens arrive at different definitions of these terms, the degree to which discussion across differences can or will occur becomes unclear. At this point in her argument, Edenberg seems to ignore that citizens "are difficult people" (Gutmann, 1990, p. 7) constantly attempting to navigate the "tension between individual freedom and civic virtue" (Gutmann, 1990, p. 7). It is highly unlikely that every pair of citizens will hold the same ideas about what constitutes domination and subordination, so to arrive at and force acceptance of a single definition would rob each both participants of their individual conceptualizations. To play this scenario out a bit, voting for Trump may violate the minimum standards for reciprocal respect and reasonableness for some citizens but not for others. Defining 'voting for Trump' as an act of domination and subordination precludes over 62 million citizens from reciprocal respect and reasonableness, but Edenberg does not provide direction about ways to navigate instances where the difference in definitions removes a portion of the population from receiving reciprocal respect and reasonableness during discussions with other citizens. If Edenberg (2018) believes that discussion is key to "combat...forms of inequality" (p. 2) then Edenberg's proposal in favor of developing reasonableness must include mechanisms to navigate definitional differences about what specifically constitutes domination and subordination. Without clarity around ways to navigate definitional differences, Edenberg delivers an idealistic but untenable theory to increase discussion across lines of difference.

\section{References}

Edenberg, E. (2018). Cultivating reasonableness in future citizens. On Education. Journal for Research and Debate, 1(1). https://doi.org/10.17899/on_ed.2018.1.8

Gutmann, A. (1990). Democratic education in difficult times. Teachers College Record, 92(1), 7-20.

Levinson, N. (1997). Teaching in the midst of belatedness: the paradox of natality in Hannah Arendt's educational thought. Educational Theory, 47(4), 435-451. https://doi.org/10.1111/j.1741-5446.1997.00435.x

Posner, E. (2015, February 12). Colleges need speech codes because their students are still children. Slate Magazine. Retrieved from https://slate.com/news-and-politics/2015/02/university-speech-codes-students-are-children-who-mu st-be-protected.html 
Zimmerman, J. (2016). Campus politics: What everyone needs to know $($. New York, NY: Oxford University Press.

\section{Recommended Citation}

Callahan, P. (2019). Reply: A Response to Cultivating Reasonableness in Future Citizens by Elizabeth Edenberg. On Education. Journal for Research and Debate, 1(1). https://doi.org/10.17899/on_ed.2018.1.14

\section{Download PDF version}

Do you want to comment on this article? Please send your reply to editors@oneducation.net. Replies will be processed like invited contributions. This means they will be assessed according to standard criteria of quality, relevance, and civility. Please make sure to follow editorial policies and formatting guidelines.

\section{pamela callahan}

Pamela Callahan is a Ph.D. student at the University of Maryland, College Park. Her research interests broadly focus on the intersection of schools and democracy, specifically on school boards, civics education, and teacher preparation. 